\title{
Manufacturing of Chamotte Refractory Brick from Clay Sources in Vietnam
}

\author{
Minh Tri Trương, Thanh Minh Pham ${ }^{2}$, Ngoc Hieu Phan ${ }^{1}$, Thi Diem Nguyen ${ }^{1}$, Thi Xuan Quy \\ Nguyen ${ }^{1}$, Minh Thuy Dang, ${ }^{3}$, Van Thuan Le ${ }^{4}$ and Hoai Thuong Nguyen ${ }^{5,6, *}$ \\ ${ }^{I}$ The Mientrung Institute for Chemistry and Environment Research, Mien Trung University of Civil Engineering, Tuy Hoa, Phu Yen, \\ Vietnam. \\ ${ }^{2}$ Nuclear Research Institute, Da Lat, Vietnam. \\ ${ }^{3}$ Vietnam-Russia Tropical Centre, Ha Noi, Vietnam. \\ ${ }^{4}$ Center for Advanced Chemistry, Institute of Research \& Development, Duy Tan University, Danang, Vietnam. \\ ${ }^{5}$ Division of Computational Physics, Institute for Computational Science, Ton Duc Thang University, Ho Chi Minh City, Vietnam. \\ ${ }^{6}$ Faculty of Electrical \& Electronics Engineering, Ton Duc Thang University, Ho Chi Minh City, Vietnam
}

Received 23 July 2018; Accepted 19 September 2018

\begin{abstract}
The article studies the use of refractory materials from natural clay and kaolin sources in the Southern Central - Central Highlands, Vietnam to manufacture chamotte refractory bricks meeting the need for localization of refractory products. Methods for study of material composition such as SEM, Energy Dispersive X-Ray, X-Ray Diffraction, DTA-TG, and methods for study of physico-mechanical properties of chamotte refractory bricks are used. As a result, the chamotte refractory brick manufacturing process from natural clay and kaolin sources has been developed. The physico-mechanical properties of chamotte fire bricks after firing have met the refractory requirement of $1580^{\circ} \mathrm{C}$. This product has also contributed to replace the imported materials for the sector of general refractory materials in Vietnam.
\end{abstract}

Keywords: Chamotte, refractory brick, clay, kaolin

\section{Introduction}

Refractory materials have been formed and developed since the late $19^{\text {th }}$ century. By the early $20^{\text {th }}$ century, refractory materials develop rapidly to meet the needs of metallurgical technology and other tech industries such as construction materials, ceramics, etc [1]. These industries require a large amount of refractory bricks used in furnace systems. Therefore, the development of refractory bricks is indispensable for many different industries.

In recent years, there have been many studies on chamotte refractory bricks from clay and kaolin.

In 2003, Abu - Hamattech et al. studied on improvement of chemical composition and heat treatment of original materials made of kaolinite clay for manufacturing of refractory bricks, by adding $\mathrm{Al}_{2} \mathrm{O}_{3}$ to the original materials and then carrying out heat treatment to obtain satisfactory chamotte to manufacture refractory bricks [2]. In 2010, Marwa A.G. Elngar et al. studied on manufacturing of refractory bricks from available materials in Egypt such as ceramic powder, bentonite and clay. The results showed that if increasing over $1.5 \%$ of ceramic powder, bentonite and clay, the shrinkage, porosity and water absorption of refractory bricks decreased, while volumetric mass and strength upon compression increased [3]. In 2012, Jordanian authors applied the manufacturing of chamotte refractory bricks from clay with refractory capacity of $1180-1450^{\circ} \mathrm{C}$ [4]. Also in 2012, Atanda. P et al. studied on the heat

*E-mail address: nguyenhoaithuong@tdtu.edu.vn

ISSN: 1791-2377 @ 2018 Eastern Macedonia and Thrace Institute of Technology. All rights reserved. doi:10.25103/jestr.114.03 treatment of original materials made of clay and ceramic powder to manufacture refractory bricks. The results obtained from $20-30 \%$ of ceramic powder and $70-80 \%$ of clay met the physico-chemical and technical requirements to produce refractory bricks [5]. In 2013, Nigerian authors studied on the manufacturing of chamotte refractory bricks from clay which were used in furnaces, incinerators and reactors. As a result, refractory bricks had a refractory capacity of $1600^{\circ} \mathrm{C}$ and satisfied the physico-chemical criteria of refractory bricks [6]. In 2014, the authors, Osarenmwinda Jo, Abel and Chukwuemeka Philip, studied on the application of clay sources in Nigeria to produce chamotte refractory bricks for furnaces and stoves with the refractory capacity of bricks higher than $1600^{\circ} \mathrm{C}$ and good insulation [7].

However, these studies used natural materials with chemical composition that do not fully meet the conditions for manufacturing of refractory bricks. Therefore, mixing composition such as $\mathrm{Al}_{2} \mathrm{O}_{3}$, ceramic powder, etc., leading to high price of the product.

In Vietnam, the demand of refractory material industries is increasing, the number of factories manufacturing refractory bricks is not enough to supply, hence import from foreign countries with high price is required. Especially in the South Central - Central Highlands region, many clay and kaolin mines with large reserves are available, but only a few studies on application of this material sources for manufacturing of refractory bricks are conducted. This is a good condition and an urgent task to apply clay and kaolin in this region for the study, manufacturing and test of chamotte refractory bricks towards the replacement of material sources in traditional manufacturing areas and imported materials for the refractory material sector in general. 


\section{Materials and Methods}

\subsection{Materials}

Clay test samples are collected from mining facilities in Phu Yen (Vietnam). Kaolin is collected in Khanh Hoa (Vietnam). Clay and kaolin test samples become dry naturally for one month, then are crushed and sieved through a sieve with a hole diameter of $1.8 \mathrm{~mm}$.

\subsection{Analysis of chemical composition}

The chemical composition of clay and kaolin is determined by the method of Energy Dispersive X-Ray (EDX, SEM Quanta 200 3D, Japan) [8]. The loss on ignition (LOI) is determined by the Lechler and Desiletes method [9].

\subsection{Methods for study on structure of materials}

The method of Scanning Electron Microscope (SEM) provides morphological information of the material to be identified, SEM images of the test sample are recorded on Quanta 200 3D machine made in Japan [8]. The mineral composition of materials is determined by the method of XRay Diffraction (XRD, Rigaku Ultima IV, Japan) [10]. The thermal analysis method (DTA - TG) studies the processes that arise upon heating up or cooling down the substance. Diagrams represent the change in properties over time are built. Based on these diagrams, it is possible to deduce the composition and many other data of substances upon occurrence of thermal effects [11].

\subsection{Refractoriness}

Pyrometric Cone Equivalent (PCE) is used to measure the refractoriness of the studied test samples. Refractoriness tests are used with standard cones and testing cones in the same firing condition of the test samples (Testing cone is prepared from the test samples and has the same size as standard cone). After that, standard cone and testing cone are placed in an electric furnace PCE and heated up. The temperature is raised to $1000-1500^{\circ} \mathrm{C}$ at a speech of $15-$ $20^{\circ} \mathrm{C} / \mathrm{min}$ and $1500-1600^{\circ} \mathrm{C}$ at a speech of $4-5^{\circ} \mathrm{C} / \mathrm{min}$ until the head of testing cone reaches the surface of the plate where cone is placed. The drooping of testing cone compared to standard cone will determine the refractoriness of the test sample [12].

\subsection{Shrinkage property}

The shrinkage of test samples is determined by changing dimension between drying in a drying oven $\left(110 \pm 5^{\circ} \mathrm{C}\right.$ for 6 hours) and firing in the furnace YF-1600 $\left(1300^{\circ} \mathrm{C}\right.$ at a speech of $5^{\circ} \mathrm{C} / \mathrm{min}$ ) [13]. The shrinkage (Y, \%) is calculated by formula (1):

$$
Y=\frac{L_{d}-L_{f}}{L_{d}} 100
$$

Where: $\mathrm{L}_{\mathrm{d}}$ is the dried dimension; $\mathrm{L}_{\mathrm{f}}$ is the fired dimension.

\subsection{Deformative Temperature.}

Prepare a cylindrical test sample with a diameter of $36 \pm 0.5$ $\mathrm{mm}$ and a height of $50 \pm 0.5 \mathrm{~mm}$. Bottoms of the test sample must be planar, parallel and polished, so that, between two random measurements, the difference in height of the test sample must not be greater than $0.2 \mathrm{~mm}$. Place the test sample onto the glaphit load transmission shaft in the middle of the firing zone, where the highest temperature is available, the test sample must be placed at the center as compared to the furnace wall and the load transmission shaft of $0.2 \mathrm{~N} / \mathrm{m}^{2}$. The heat increase speech in the furnace must be even and gradual. When the temperature is below $1000^{\circ} \mathrm{C}$, the heat increase speech is $8-10^{\circ} \mathrm{C} / \mathrm{min}$. When the temperature is over $1000^{\circ} \mathrm{C}$, the heat increase speech is 4 $5^{\circ} \mathrm{C} / \mathrm{min}$. Measure the temperature in the furnace with a thermometer when the temperature is below $1300^{\circ} \mathrm{C}$ [13].

\subsection{Compressive Strength}

The test samples are dried in a drying oven at $110 \pm 5^{\circ} \mathrm{C}$ for 6 hours and then cooled down to room temperature. Measure the horizontal cross section $\mathrm{S}\left(\mathrm{mm}^{2}\right)$. Subsequently, the test samples are placed onto a hydraulic compressor and compressed a force of $\mathrm{F}(\mathrm{N})$ until the test samples are completely destroyed [14]. The compressive strength $\left(\mathrm{R}_{\mathrm{n}}\right.$, $\mathrm{N} / \mathrm{mm}^{2}$ ) is calculated by the formula (2):

$$
R_{n}=\frac{F}{S}
$$

\subsection{Apparent porosity and volumetric mass}

Dry the test sample at $110^{\circ} \mathrm{C} \pm 5^{\circ} \mathrm{C}$ till constant weight. Cool it in a desiccator. Use a caliper to measure three dimensions of the test sample (length 1 , width $b$, height $h$ ) and weigh dry weight $\left(\mathrm{m}_{1}\right)$. Next, put the test sample in a jar and pour water into such jar so that the water level is higher than the test sample $20 \mathrm{~mm}$. Heat up the test sample for 3 hours since water is boiling and cool down to room temperature. Take the test sample out and weigh it $\left(\mathrm{m}_{2}\right)$. Then, hang the test sample at the hanging point of one side of the balance by a thin copper wire, weigh the test sample when it is fully immersed in water $\left(\mathrm{m}_{3}\right)$ [14]. (3):

The apparent porosity $\left(\mathrm{X}_{\mathrm{ap}}, \%\right)$ is calculated by formula

$$
X_{a p}=\frac{m_{2}-m_{1}}{m_{2}-m_{3}} * 100
$$
formula (4):

The volumetric mass $\left(\gamma, \mathrm{g} / \mathrm{cm}^{3}\right)$ is calculated by

$$
\gamma=\frac{m_{1}}{l \times b \times h}
$$

Where: $1, b, h$ is respectively length, width, height of the test sample $(\mathrm{cm})$.

\subsection{Moisture content}

Moisture content is determined by the loss of weight of the test sample by drying to a constant weight. The test sample is dried to a constant weight - when the minimum difference between the last two weighings is reached (but not greater than $0.02 \mathrm{~g}$ ). The moisture content is calculated as the percentage by weight of the dried test sample [15].

\subsection{Manufacturing of chamotte refractory bricks}

Prepare clay as a binder: Break clay into small pieces, dry at $110-120^{\circ} \mathrm{C}$ for 48 hours to achieve a moisture content of about $5-7 \%$. Then, grind to grain size lesser $1.5-2 \mathrm{~mm}$ and sieve to grain size about $1 \mathrm{~mm}$ [16].

Prepare chamotte thining addictive: Chamotte is a thinning addictive that helps reduce shrinkage during drying and firing, made of clay and kaolin fired till chemical 26 
refractory clay and kaolin, with a percentage of blended weight of 50:50. Then, conduct plasticized pressing into bricks, dry them and fire to a combination temperature of $1200-1250^{\circ} \mathrm{C}$ for 24 hours [17].

Mixing stage: Apply $50-80 \%$ of chamotte weight to a concrete mixer, rotate the mixer evenly, then pump water into the mixer to moisten, when chamotte is uniformly moist, apply $50-20 \%$ of weight of milled moist refractory clay (moisture 30\%) to such mixer, continue to rotate the mixer for about 10 minutes until the chamotte and clay are uniform, then discharge the material. After that, brew for 24 hours so that the mixture is uniformly moistened and increase the adhesive capacity upon shaping [12].

Shaping: The shaping is carried out by twice plasticized pressing using a LAEIBUCHER hydraulic compressor with a compression force of 1600 tons under a pressure of 400 $\mathrm{kg} / \mathrm{cm}^{2}$.
Drying: Dry bricks in the drying oven at $105^{\circ} \mathrm{C}$ for 30 hours [18].

Firing: Fire bricks at $1400^{\circ} \mathrm{C}$ with a heat increase speech of $30^{\circ} \mathrm{C} / \mathrm{h}$ using YF - 1600 muffle furnace for 45 hours. Then cool bricks at a speech of about $60-70^{\circ} \mathrm{C} / \mathrm{h}$ for $50-60$ hours [19].

\section{Results and discussion}

\subsection{Characteristics of the raw materials}

Results of analysis of chemical composition of kaolin and clay samples in the South Central - Central Highlands region by Energy Dispersive X-Ray (EDX) method are as follows (Table 1 and Figure 1).

Table 1. Chemical composition of raw materials

\begin{tabular}{c|c|c|c|c|c|c|c|c|c}
\hline \multirow{2}{*}{ Sample } & \multicolumn{10}{c}{ Chemical composition (wt.\%) } \\
\cline { 2 - 10 } & $\mathrm{SiO}_{2}$ & $\mathrm{Al}_{2} \mathrm{O}_{3}$ & $\mathrm{Fe}_{2} \mathrm{O}_{3}$ & $\mathrm{TiO}_{2}$ & $\mathrm{Na}_{2} \mathrm{O}$ & $\mathrm{MgO}$ & $\mathrm{K}_{2} \mathrm{O}$ & $\mathrm{CaO}$ & $\mathrm{LOI}$ \\
\cline { 1 - 11 } Kaolin & 61.45 & 27.14 & 1.84 & 1.73 & 0.34 & 0.72 & 0.32 & 0.81 & 5.65 \\
Clay & 54.68 & 25.87 & 2.21 & 1.74 & - & 1.15 & 2.10 & 1.36 & 10.89 \\
\hline
\end{tabular}

LOI: Loss on ignition

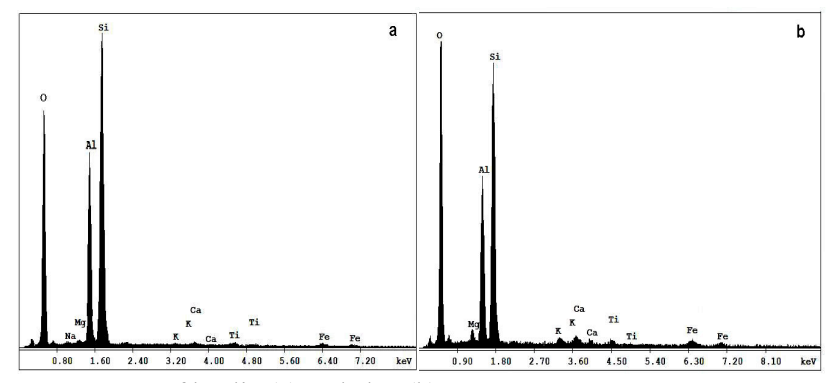

Fig. 1. EDX of kaolin (a) and clay (b)

Table 1 shows that $\mathrm{SiO}_{2}$ and $\mathrm{Al}_{2} \mathrm{O}_{3}$ are the dominant components in both kaolin and clay. Kaolin sample has a $\mathrm{Al}_{2} \mathrm{O}_{3}$ content of $27.14 \%$ and clay sample has a $\mathrm{Al}_{2} \mathrm{O}_{3}$ content of $25.87 \%$ in the value range of $23-45 \% \mathrm{Al}_{2} \mathrm{O}_{3}$ in respect of refractory materials under the Standard (Handbook of Refractory Practice) [20]. The higher $\mathrm{Al}_{2} \mathrm{O}_{3}$ content in clay is, the higher refractory capacity is. The high percentage of weight of $\mathrm{SiO}_{2} 61.45 \%, \mathrm{Al}_{2} \mathrm{O}_{3} 27.14 \%$ and LOI $5.65 \%$ of kaolin and $\mathrm{SiO}_{2} 54.68 \%, \mathrm{Al}_{2} \mathrm{O}_{3} 25.87 \%$ and LOI $10.89 \%$ of clay show that kaolin and clay are hydrogen aluminosilicate minerals. Hydrogen aluminosilicates are highly dispersed, which, when combining with water, forms a plasticized mass that retains its shape after drying and has a very hardening strength after firing. The results in Table 1 also indicate that the content of $\mathrm{Fe}_{2} \mathrm{O}_{3}$ is $1.84 \%$ in kaolin and $2.21 \%$ in clay, which is in line with the Standard [20] for refractory materials with content of $\mathrm{Fe}_{2} \mathrm{O}_{3}$ less than $0.3-$ 4\%. In addition, the presence of other oxide impurities such as $\mathrm{TiO}_{2}(1.73-1.74 \%), \mathrm{Na}_{2} \mathrm{O}(0.34 \%), \mathrm{CaO}(0.81-$ $1.36 \%), \mathrm{MgO}(0.72-1.15 \%)$ and $\mathrm{K}_{2} \mathrm{O}(0.32-2.10 \%)$ accounting for low percentages in weight, but all of which are in the range of refractory bricks.

The results of analysis of X-ray diffraction of kaolin and clay (Figure 2) present the mineral components as follows: Kaolin has a very high kaolinite content (86\%), quartz $(10 \%)$, montmorillonite $(3 \%)$ and illite $(1 \%)$, in which clay has a lower kaolinite content $(80 \%)$, quartz $(9 \%)$, montmorillonite $(5 \%)$, illite $(4 \%)$ and chlorite $(2 \%)$. The kaolinite contents in clay and kaolin are high, accounting for $80-86 \%$, indicating that a high $\mathrm{Al}_{2} \mathrm{O}_{3}$ content is the major component of refractory materials at high temperature. Quartz contents in both clay and kaolin are low, accounting for about $9-10 \%$, indicating that $\mathrm{SiO}_{2}$ contents are low, because if $\mathrm{SiO}_{2}$ content is more than $70 \%$, it will reduce the flexibility and refractory capacity, raise the combination capacity and in some cases will detach clay when firing at high temperatures. The montmorillonite content in clay and kaolin is a non-refractory component and highly easy to dilate when exposing to water, accounting for a low content of $3-5 \%$. In addition, the content of illite and chlorite show a characteristic of being highly easy to dilate when exposing to water but accounting for a low content of $1-4 \%$.

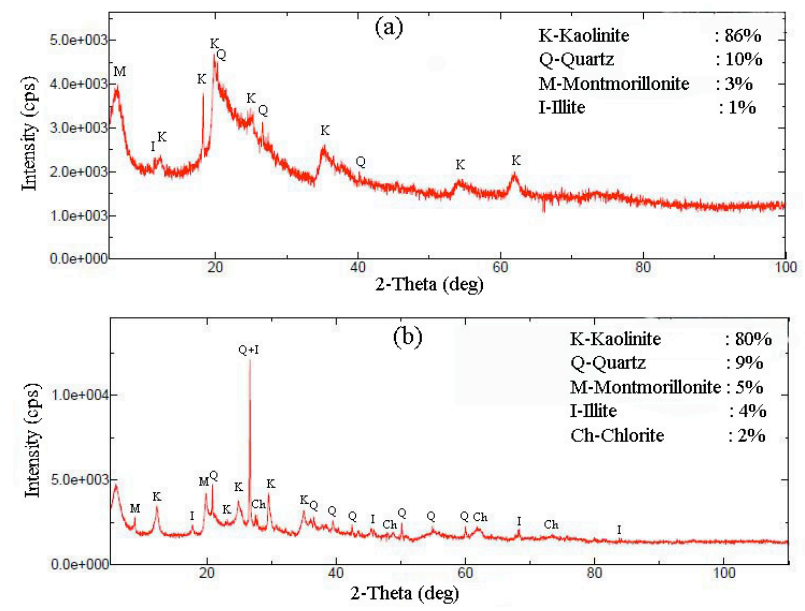

Fig. 2. XRD of clay (a) and kaolin (b)

In addition, the results of analysis to determine properties of refractoriness and moisture content of clay and kaolin in the South Central - Central Highlands region are shown in Table 2. 
Table 2. Physical properties of raw materials.

\begin{tabular}{c|l|c|c|c}
\hline \multicolumn{1}{|c|}{ Properties } & Clay & Kaolin & Standard \\
\hline 1 & Aluminum oxide $\left(\mathrm{Al}_{2} \mathrm{O}_{3}\right)$ content $(\%)$ & 25.87 & 27.14 & $>23$ \\
\hline 2 & Iron oxide $\left(\mathrm{Fe}_{2} \mathrm{O}_{3}\right)$ content $(\%)$ & 2.21 & 1.84 & $<4.0$ \\
\hline 3 & Refractoriness $\left({ }^{\circ} \mathrm{C}\right)$ & 1585 & 1600 & $>1580$ \\
\hline 4 & Moisture content $(\%)$ & 6.23 & 6.42 & $<7$ \\
\hline
\end{tabular}

Comparison of the above results shows that clay and kaolin in the South Central - Central Highlands region meet the requirements of the Standard (Handbook of Refractory Practice) to manufacture chamotte refractory bricks.
3.2. Chamotte refractory brick manufacturing process

Chamotte refractory brick manufacturing is carried out by plasticized pressing method and the manufacturing process is obtained as below in Figure 3.

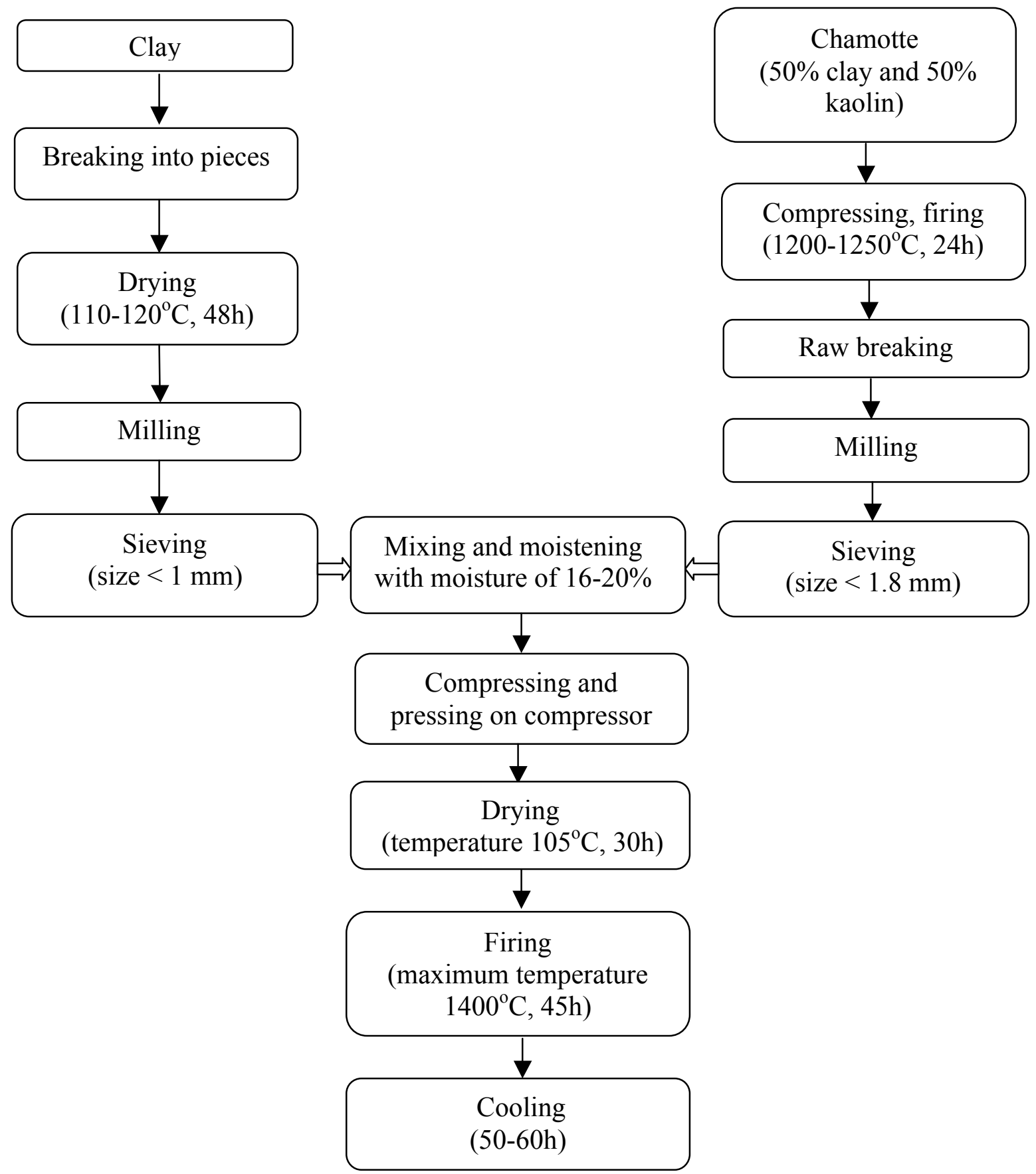

Fig. 3. Chamotte refractory brick manufacturing process.

\subsection{The physico-chemical properties of chamotte refractory bricks}

The results of analysis of the physico-chemical properties of chamotte refractory bricks after firing show that chamotte refractory bricks made of clay in the South Central - Central Highlands region, Vietnam meet the requirements of Standard (Handbook of Refractory Practice) for standard chamotte refractory bricks in Table 3 . 
Minh Tri Truong, Thanh Minh Pham, Ngoc Hieu Phan, Thi Diem Nguyen, Thi Xuan Quy Nguyen, Minh Thuy Dang, Van Thuan Le and Hoai Thuong Nguyen/Journal of Engineering Science and Technology Review 11 (4) (2018) 25 - 30

Table 3. Physico-chemical properties of chamotte refractory bricks

\begin{tabular}{|c|c|c|c|}
\hline No. & Properties & Standard & Chamotte refractory bricks \\
\hline 1 & $\mathrm{Al}_{2} \mathrm{O}_{3}$ content in $\%$, not less than & $28-35$ & 28.35 \\
\hline 2 & Refractoriness in ${ }^{\circ} \mathrm{C}$, not less than & $1580-1730$ & 1580 \\
\hline 3 & Shrinkage for two hours in $\%$, not less than & 0.7 & 0.64 \\
\hline 4 & $\begin{array}{l}\text { Temperature begining to deform under a load of } 0.2 \mathrm{~N} / \mathrm{mm}^{2} \\
\text { in }{ }^{\circ} \mathrm{C} \text {, not less than }\end{array}$ & $1200-1400$ & 1250 \\
\hline 5 & Compressive strength limit in $\mathrm{N} / \mathrm{mm}^{2}$, not less than & $12.5-20.0$ & 13.4 \\
\hline 6 & Apparent porosity in $\%$, not less than & $24-26$ & 22.82 \\
\hline 7 & Volumetric mass in $\mathrm{g} / \mathrm{cm}^{3}$, not less than & $1.9-2.0$ & 2.0 \\
\hline
\end{tabular}

By analyzing of the physico-chemical change process after firing at $1400^{\circ} \mathrm{C}$ of chamotte refractory bricks by thermal analysis method DTA-TG (Figure 4), it is shown that during increase of heat from $21^{\circ} \mathrm{C}$ to $1000^{\circ} \mathrm{C}$, the change in sample weight is very low, around $0.05 \%$, indicating that chamotte refractory bricks do not undergo a physicochemical change process after firing at $1400^{\circ} \mathrm{C}$ but are mullitized to form a tightly bound block.

Assessment of the quality of chamotte refractory bricks using the method of Scanning Electron Microscope (SEM) helps in determining size and distribution of chamotte particles. It is significant in not only quantity but also shape, size and orientation. The SEM results of the samples of kaolin, clay, chamotte and chamotte refractory bricks are shown in Figure 5.
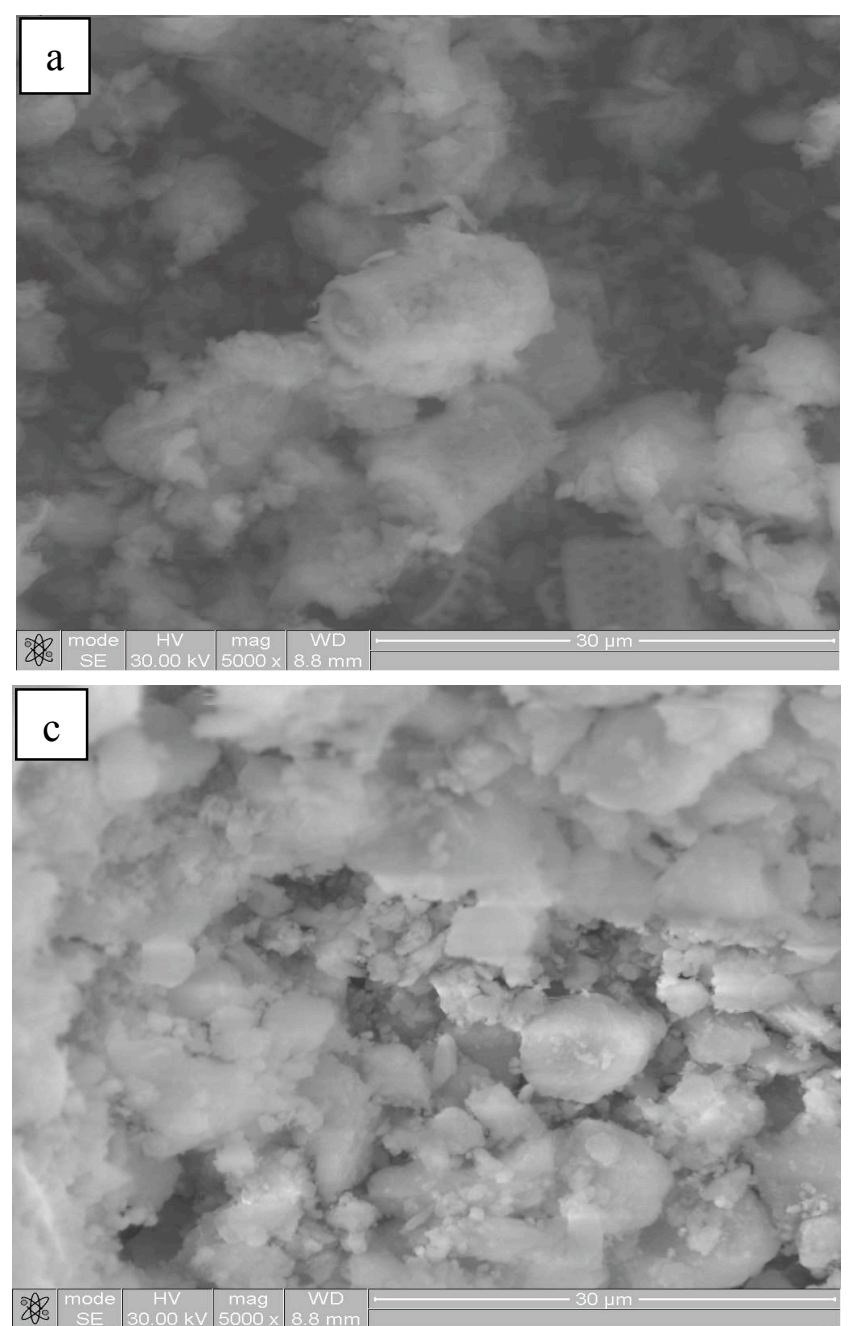

Fig. 5. SEM images of kaolin (a), clay (b), chamotte (c) and chamotte refractory bricks (d)
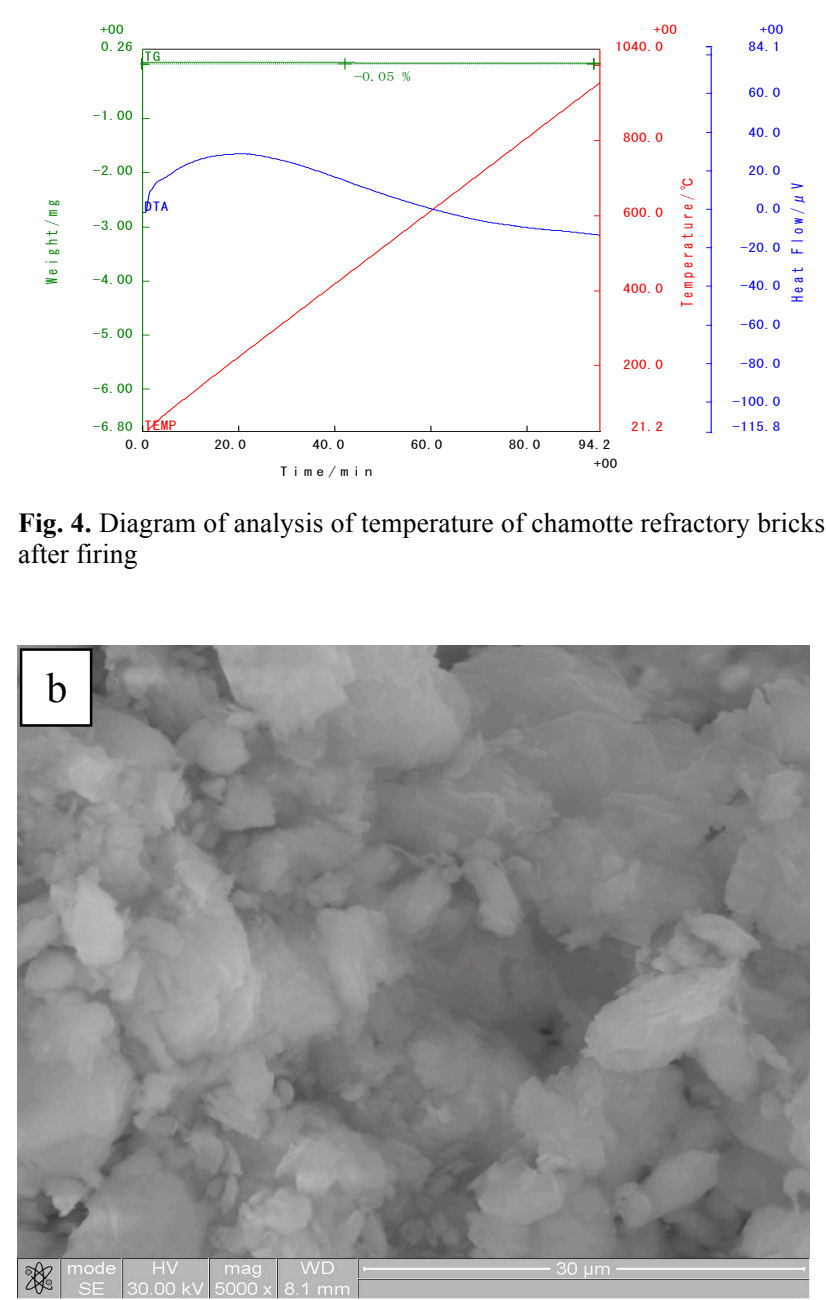

Fig. 4. Diagram of analysis of temperature of chamotte refractory bricks after firing

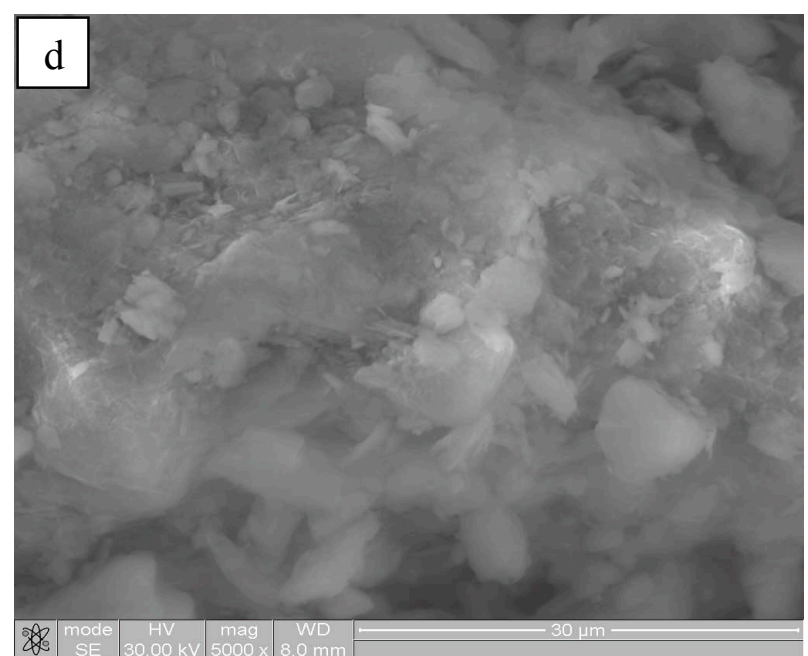


The results show that kaolin (a) and clay (b) samples have a porous structure and a plate shape with a particle size of about $30 \mu \mathrm{m}$, particle size of the chamotte (c) sample is distributed evenly well. The SEM image of chamotte refractory bricks (d) shows that chamotte particles are tightly bound to clay and evenly distributed. It indicates that clay and chamotte particles are mullitized and mullite crystals are oriented in all directions in the whole matter.

\section{Conclusions}

Clay and kaolin in the South Central - Central Highlands region have been tested for physico-chemical analysis to exam its potential in manufacturing of chamotte refractory bricks. The results of study on chemical composition of clay and kaolin and the physico-chemical properties of chamotte refractory bricks after firing are in the range for chamotte refractory bricks. From the obtained results, we have developed a chamotte refractory brick manufacturing process based on clay (Phu Yen) and kaolin (Khanh Hoa) in the South Central, Vietnam. Therefore, it is concluded that the clay mines there are suitable for mining and will be used to manufacture high-temperature chamotte refractory bricks to meet the increasing demand for use in practice.

\section{Conflicts of Interest}

The authors declare that there is no conflict of interest regarding the publication of this paper.

This is an Open Access article distributed under the terms of the Creative Commons Attribution Licence

\section{References}

1. R. A. Heindl and W. L. Pendergast, J. Am. Ceram. Soc. 13, 725 (1930).

2. Z. S. H. Abu-Hamatteh and M. Al-Taie, Pakistan J. Appl. Sci. 3, 103 (2003).

3. M. A. G. Elngar, F. M. Mohamed, G. Asrar, C. M. Sharaby, and M. E. H. Shalabi, J. Ore Dress.11, 25 (2009).

4. S. M. Fayyad, G. S. Al-Marahleh, and S. Q. Abu-Ein, Adv. Theor. Appl. Mech. 5, 161 (2012).

5. P. Atanda, O. Adeniji, and O. Oluwole, Int. J. Mater. Chem. 2, 185 (2012).

6. A. A. Jock, F. A. Ayeni, L. S. Jongs, and N. S. Kangpe, Int. J. Mater. Methods Technol. 1, 189 (2013).

7. J. Osarenmwinda and C. P. Abel, J. Appl. Sci. Environ. Manag. 18, 151 (2014).

8. J. T. SanAgustin, J. A. Follit, G. Hendricks, and G. J. Pazour, Scanning electron microscopy to examine cells and organs, in Methods in cell biology, Elsevier, p. 81-87 (2009).

9. P. J. Lechler and M. O. Desilets, Chem. Geol. 63, 341 (1987).

10. J. Epp, X-ray diffraction (XRD) techniques for materials characterization, in Materials Characterization Using Nondestructive Evaluation (NDE) Methods, Elsevier, p. 81-124
(2016).

11. M. Feist, ChemTexts. 1, 8 (2015).

12. S. Caniglia and G. L. Barna, Handbook of industrial refractories technology: principles, types, properties and applications, William Andrew (1992).

13. H. Shikano, Refractories handbook, Tech. Assoc. Refract. Japan, p. 170-182 (1998).

14. C. ASTM, 67-03, Standard test methods for sampling and testing brick and structural clay tile, Am. Soc. Test. Mater, Philadelphia, PA (2003).

15. C. L. Deeds, J. Am. Ceram. Soc. 13, 200 (1930).

16. A. R. Chesti, Refractories: manufacture, properties and applications, Prentice-Hall of India (1986).

17. M. Barsoum and M. W. Barsoum, Fundamentals of ceramics, CRC press (2002).

18. M. S. Jennings and A. H. Laube, Source Category Survey: Refractory Industry (1980).

19. F. H. Norton, Refractories (1968).

20. H.-W. Refractories, Handbook of Refractory Practice, HarbisonWalker Refract. Co., (2005). 